\title{
Assignment of Listeria grayi and Listeria murrayi to a Single Species, Listeria grayi, with a Revised Description of Listeria grayi
}

\author{
JOCELYNE ROCOURT, ${ }^{1 *}$ PATRICK BOERLIN ${ }^{2}$ FRANCINE GRIMONT ${ }^{3}$ \\ CHRISTINE JACQUET ${ }^{1}$ AND JEAN-CLAUDE PIFFARETTI ${ }^{2}$ \\ Centre National de Référence pour la Lysotypie et le Typage Moléculaire de Listeria and WHO Collaborating Center for \\ Foodborne Listeriosis, Département de Bactériologie-Mycologie, ${ }^{1}$ and Unité des Entérobacteries, Centre National de \\ Référence pour le Typage Moléculaire Entérique, Unité INSERM 199, ${ }^{3}$ Institut Pasteur, 28 rue du Dr Roux, \\ 75724 Paris, Cedex 15, France, and Istituto Cantonale Batteriologico, 6904 Lugano, Switzerland $^{2}$
}

The genomic relatedness between Listeria grayi and Listeria murrayi was reevaluated by using DNA-DNA hybridization, multilocus enzyme electrophoresis, and rRNA restriction fragment length polymorphism techniques. The high levels of similarity observed between the strains of these two species confirmed the data published since 1973 and indicated that they should be considered members of a single species. On grounds of priority, the species should be named $L$. grayi.

DNA-DNA hybridization and 16S rRNA sequencing results have shown that the genus Listeria consists of two distinct groups of genomically related species; Listeria monocytogenes, Listeria innocua, Listeria ivanovii, Listeria welshimeri, and Listeria seeligeri are in one group, and Listeria grayi and Listeria murrayi are in the second group $(3,13,15)$

L. grayi Errebo Larsen 1966 (11) and L. murrayi Welshimer and Meredith 1971 (25) are isolated very rarely (14) and are nonpathogenic (5). The status of these organisms as two distinct species is unclear, and their status in the genus was left as species incertae sedis by Seeliger and Jones (18). In 1973, Stuart and Welshimer observed a high level of DNA-DNA homology between strains of $L$. grayi and $L$. murrayi (21) and subsequently proposed that they should be placed in a single species (22). However, this proposal was not put into effect on the Approved Lists of Bacterial Names (20), nor was it validated by a subsequent publication, possibly because Stuart and Welshimer (22) proposed exclusion of these two species from the genus Listeria and their transfer to a new genus, "Murraya," as "Murraya grayi subsp. grayi" and "Murraya grayi subsp. murrayi" (22).

The close relationship between these two species has been shown by numerical taxonomic analyses, which grouped them as a single distinct cluster with a level of similarity of 85 to $90 \%(6,26)$, as well as by multilocus enzyme analysis $(2)$. Furthermore, the sharing of specific chemotaxonomic properties distinguish these organisms from other members of the genus Listeria and support their close relationship; they have the same DNA base composition values $(6,21)$, produce similar electropherograms for whole-cell proteins (10), and exhibit identical substitutions of the lipoteichoic acids (16) and a common antigenic structure (17), with small differences in $O$ factors (23). Finally, the two species have been distinguished from each other only on the basis of nitrate reduction data (18).

In this study we thoroughly reexamined the genomic distance between $L$. grayi and $L$. murrayi in order to evaluate whether these two taxa should be retained. To do this, we used the following three methods: DNA-DNA hybridization, multilocus enzyme electrophoresis, and rRNA gene restriction fragment length polymorphism.

\footnotetext{
* Corresponding author.
}

\section{MATERIALS AND METHODS}

Bacterial strains. The designations and sources of the five strains of $L$. grayi and the five strains of $L$. murrayi used in this study are shown in Table 1 . These organisms were identified by using well-recognized biochemical markers (18).

DNA-DNA hybridization. DNA-DNA hybridization experiments were performed as previously described (13), except that we used the procedure described below to lyse the bacteria. The growth from six Roux flasks that were incubated for $48 \mathrm{~h}$ at $37^{\circ} \mathrm{C}$ and contained $150 \mathrm{ml}$ of Columbia agar was harvested, washed in $20 \mathrm{ml}$ of $0.1 \times \mathrm{SSC}(1 \times \mathrm{SSC}$ is 0.15

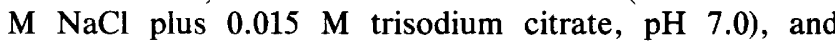
incubated for $1 \mathrm{~h}$ at $37^{\circ} \mathrm{C}$ in $5 \mathrm{ml}$ of a lysozyme solution $(0.01$ M sodium phosphate-20\% sucrose [pH 7] containing $12 \mathrm{mg}$ of lysozyme [Appligène, France]). Then we added $40 \mathrm{ml}$ of a proteinase $\mathrm{K}$ solution $(10 \mathrm{mM}$ Tris- $\mathrm{HCl}[\mathrm{pH} 8], 1 \mathrm{mM}$ EDTA, $1 \%$ sodium dodecyl sulfate, $20 \mathrm{mg}$ of proteinase $\mathrm{K}$ [Appligène]), and the mixture was incubated for $2 \mathrm{~h}$ at $37^{\circ} \mathrm{C}$. The DNA was then sequentially extracted by using phenol and chroroform and hybridized by using the S1 nucleasetrichloroacetic acid method.

Multilocus enzyme electrophoresis. The methods used and results obtained with 18 enzymes have been described previously (2).

rRNA gene restriction pattern. Chromosomal DNAs were extracted and digested with EcoRI or HindIII. The resulting fragments were subjected to electrophoresis, transferred to a nitrocellulose membrane, and hybridized with a cloned rDNA (genes coding for rRNA) from Bacillus subtilis that was labeled with $\left[\alpha-{ }^{32} \mathrm{P}\right] \mathrm{dCTP}$ by using previously described methods $(4,9)$.

\section{RESULTS AND DISCUSSION}

The results of the DNA-DNA homology experiments indicated that there were high levels of relatedness among all of the strains which we used. Labeled DNA from $L$. grayi CLIP $12518^{\mathrm{T}}$ ( $\mathrm{T}=$ type strain) was 83 to $94 \%$ (average, $87 \%$ ) related to unlabeled DNAs from $L$. murrayi strains; similarly, labeled DNA from $L$. murrayi CLIP $12515^{\mathrm{T}}$ was 78 to $88 \%$ (average, $83 \%$ ) related to unlabeled DNAs from $L$. grayi strains. The $\Delta T_{m}$ values ranged from 0 to $0.9^{\circ} \mathrm{C}$ (Table 1 ). These data are in broad agreement with those obtained by Stuart and Welshimer (58 to $76 \%$ DNA homology, deter- 
TABLE 1 . Levels of relatedness between $L$. grayi and $L$. murrayi strains

\begin{tabular}{|c|c|c|c|c|c|c|}
\hline \multirow{2}{*}{$\operatorname{Strain}^{a}$} & \multirow{2}{*}{ Origin } & \multicolumn{2}{|c|}{$\begin{array}{l}\text { \% of reassociation with } \\
\text { labeled DNA from: }\end{array}$} & \multirow{2}{*}{$\begin{array}{c}\text { Isoenzyme } \\
\text { electrophoretic } \\
\text { type }\end{array}$} & \multicolumn{2}{|c|}{ Ribogroup } \\
\hline & & $\begin{array}{c}\text { Strain CLIP } \\
12518^{\mathrm{T}}\end{array}$ & $\begin{array}{c}\text { Strain CLIP } \\
12515^{\mathrm{T}}\end{array}$ & & EcoRI & HindIII \\
\hline \multicolumn{7}{|l|}{ L. grayi } \\
\hline CLIP $12518^{\mathrm{T}}\left(=\right.$ ATCC $\left.19120^{\mathrm{T}}\right)$ & Chinchilla, Denmark & $100(0)^{b}$ & 82 & 51 & EG1 & HG1 \\
\hline CLIP 640 & Cattle, Brazil & 94 & 81 & 51 & EG1 & HG1 \\
\hline CLIP 7353 & Human, Italy & 92 & 85 & 50 & EG1 & HG1 \\
\hline CLIP 14014 & Human food, France & 102 & 88 & 51 & EG1 & HG1 \\
\hline SLCC 3322 & Dog, Germany & $87(0.3)$ & 78 & 55 & EG2 & HG2 \\
\hline \multicolumn{7}{|l|}{ L. murrayi } \\
\hline CLIP $12515^{\mathrm{T}}\left(=\right.$ ATCC $\left.25401^{\mathrm{T}}\right)$ & Vegetation, United States & $87(0.9)$ & 100 & 53 & EG1 & HG1 \\
\hline CLIP $12516(=$ ATCC 25402) & Vegetation, United States & 87 & 104 & 53 & EG1 & HG1 \\
\hline CLIP 12157 (= ATCC 25403) & Vegetation, United States & $83(0.2)$ & 77 & 52 & EG3 & HG1 \\
\hline CLIP 13861 (= CIP 103213) & Cattle, France & $85(0.3)$ & 78 & 54 & EG4 & HG1 \\
\hline SLCC $3792^{\circ}$ & Germany & 95 & 86 & 56 & EG1 & HG3 \\
\hline
\end{tabular}

${ }^{a}$ CLIP, Listeria Collection, Pasteur Institute, Paris, France; SLCC, Special Listeria Culture Collection, Würzburg, Germany; ATCC, American Type Culture Collection, Rockville, Md.; CIP, Collection de l'Institut Pasteur, Paris, France.

${ }^{b}$ The values in parentheses are $\Delta T_{m}$ values (in degrees Celsius).

c Previously misidentified as L. grayi (12).

mined by using the filter method [22]) and by Bakulov et al (90\% DNA homology, determined by using the filter method [1]). Overall DNA sequence relationships as determined by DNA hybridization have become the standard basis for assessing taxonomic relationships at the species level; a species is now defined as a group of strains that share approximately $70 \%$ or greater DNA relatedness with $\Delta T_{m}$ values of less than $5^{\circ} \mathrm{C}(24)$. Therefore, it appears that $L$. grayi and $L$. murrayi constitute a single species.

On the basis of the results obtained with 18 enzymes, the five $L$. grayi and five $L$. murrayi strains formed a single

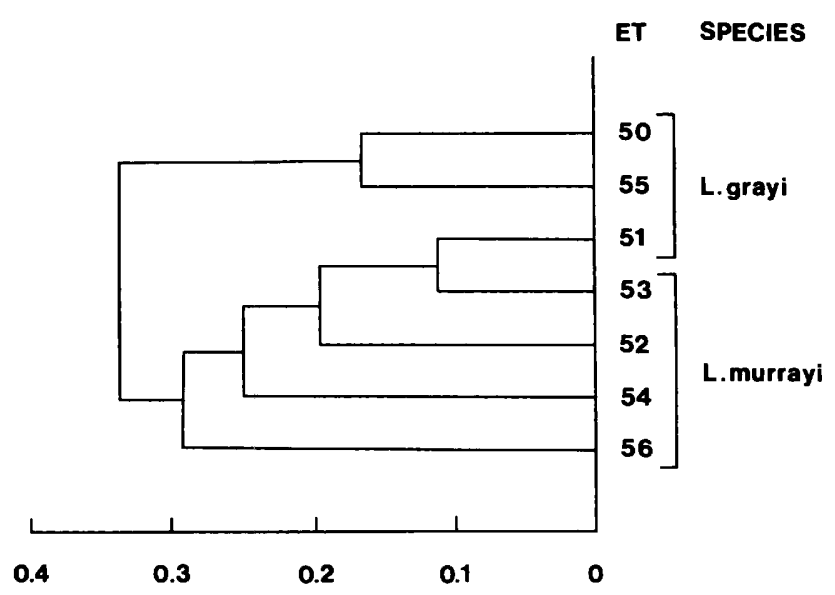

\section{GENETIC DISTANCE}

FIG. 1. Genetic relationships among the seven electrophoretic types (ETs) of $L$. grayi and $L$. murrayi. The dendrogram was generated by using the average-linkage method of clustering from a matrix of pairwise coefficients of genetic distances that were based on electrophoretically demonstrable allelic variation at 18 enzyme loci. This dendrogram is part of a dendrogram published elsewhere (2). ET 50, strain CLIP 7353; ET 55, strain SLCC 3322; ET 51, strains CLIP $12518^{\mathrm{T}}$, CLIP 640, and CLIP 14014; ET 53, strains CLIP $12515^{\mathrm{T}}$ and CLIP 12516; ET 52, strain CLIP 12517; ET 54, strain CLIP 13861; ET 56, strain SLCC 3792. major division that was distinct from the other divisions found in the genus Listeria (2). The members of this group produced seven different isoenzymes patterns, and the greatest genetic distance was 0.34 , a value far below the limit of 0.60 to 0.70 that is empirically considered to indicate separate species (Fig. 1).

Multilocus enzyme electrophoresis has been used for some years as a powerful method for evaluating genomic distances between microorganisms that are phenotypically similar (19). A recent reexamination of the taxonomy of the genus Listeria in which this method was used resulted in a

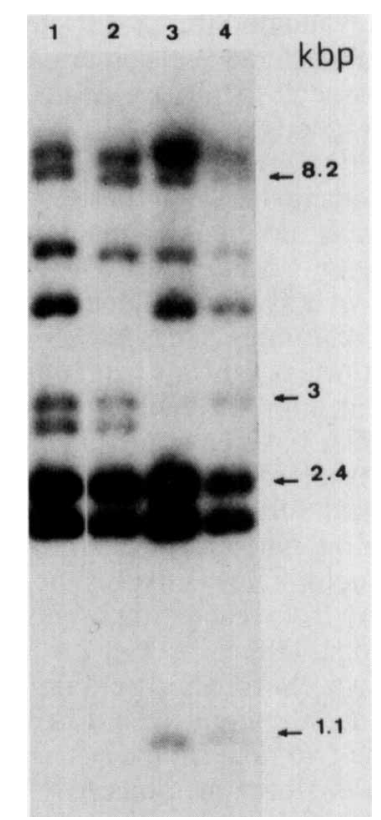

FIG. 2. Autoradiogram produced after hybridization of the rDNA probe with the following Southern-blotted EcoRI restriction fragments: lane 1, strain CLIP 640 (profile EG1); lane 2, strain SLCC 3322 (profile EG2); lane 3, strain CLIP 12517 (profile EG3); lane 4, strain CLIP 13861 (profile EG4). 

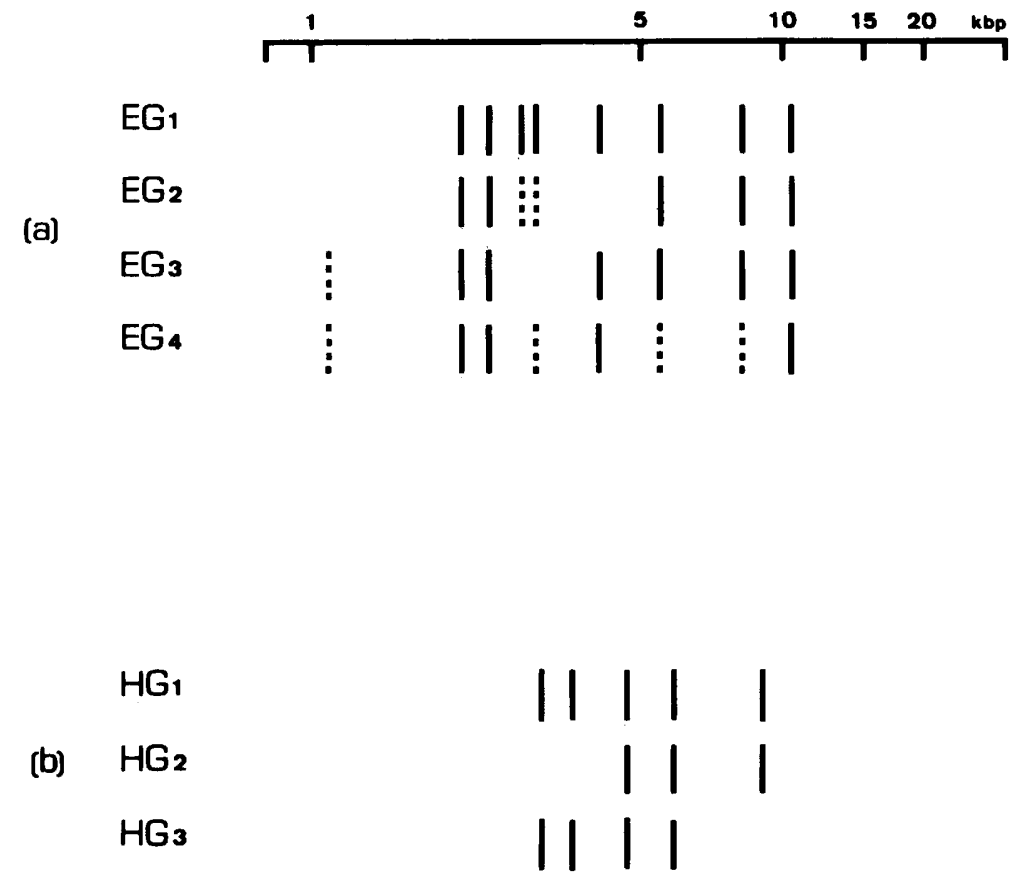

FIG. 3. Schematic representation of rRNA gene restriction patterns of $L$. grayi and L. murrayi after digestion with EcoRI (a) and HindIII (b). The dotted lines indicate weakly labeled bands.

complete correlation with a previous classification of Listeria strains as determined by DNA-DNA hybridization (2, 13). The data which we obtained reinforced the usefulness of this method for assessing closely related species.

rDNA fingerprinting is used increasingly for classification $(7,8,12)$. Our results provided further evidence of the high level of homology between $L$. grayi and $L$. murrayi. The $E c o$ RI restriction patterns of highly conserved rRNA genes obtained from the representatives of $L$. grayi and $L$. murrayi revealed four different groups (Fig. 2 and 3), which were different from the groups determined for the other Listeria species (9). Interestingly, profile EG1 was found in five $L$. grayi and three $L$. murrayi isolates, including the type strains of both species. Only three groups were detected when DNAs were digested with HindIII; one of these groups (group HG1) contained both the $L$. grayi type strain and the L. murrayi type strain (Fig. 2).

On the basis of DNA homology values, isoenzymes patterns, and rRNA genes restriction patterns, $L$. grayi and $L$. murrayi constitute a homogenous taxon, confirming the significant genomic and phenotypic similarities that have been reported since $1973(1,2,9,10,16,21,22,26)$. On grounds of priority, this taxon should be named $L$. grayi.

Emended description of $\boldsymbol{L}$. grayi. Detailed descriptions of the two former species that form $L$. grayi have been published previously in Bergey's Manual of Systematic Bacteriology (18). Brieffy, cells are small $(0.4$ to 0.5 by 0.5 to 2 $\mu \mathrm{m})$, asporogenous, gram-positive, peritrichous rods which are motile at $28^{\circ} \mathrm{C}$. Colonies on tryptose agar are small ( 1 to $2 \mathrm{~mm}$ in diameter after 1 to 2 days of incubation at $37^{\circ} \mathrm{C}$ ), regular, and smooth. Growth occurs at $4^{\circ} \mathrm{C}$ within 5 days. Metabolism is facultatively anaerobic, catalase is produced, the oxidase test is negative, and reduction of nitrates to nitrites is variable. Acid, without gas, is produced from glucose, mannitol, and other sugars. Voges-Proskauer and methyl red tests are positive. Esculin is hydrolyzed in 1 day.
Urea is not hydrolyzed, and indole is not produced. Sheep erythrocytes are not hemolyzed. Gelatin is not hydrolyzed, and $\mathrm{H}_{2} \mathrm{~S}$ is not produced. The guanine-plus-cytosine content of the DNA is $41 \mathrm{~mol} \%$.

The type strain is strain ATCC 19120 (= NCTC $10815=$ CIP 6818).

\section{ACKNOWLEDGMENTS}

We thank Névine El Sohl for the B. subtilis rDNA probe, R. G. E. Murray and P. A. D. Grimont for helpful discussions, and B. Catimel and E. Ageron for technical assistance.

Part of this research was supported by grant 31-9396.88 from the Swiss National Science Foundation and by a grant from the Swiss Veterinary Office to J.-C.P.

\section{REFERENCES}

1. Bakulov, I. A., V. M. Kotlyarov, T. P. Turova, N. B. Bakaldina, and T. L. Ivanova. 1988. Identification of Listeria by the molecular DNA-DNA hybridization technique. Mol. Gen. Microbiol. Virol. 7:31-34. (In Russian.)

2. Boerlin, P., J. Rocourt, and J.-C. Piffaretti. 1991. Taxonomy of the genus Listeria by using multilocus enzyme analysis. Int. J. Syst. Bacteriol. 41:59-64.

3. Collins, M. D., S. Wallbanks, D. J. Lane, J. Shah, R. Nietupski, J. Smida, M. Dorsch, and E. Stackebrandt. 1991. Phylogenetic analysis of the genus Listeria based on reverse transcriptase sequencing of 16S rRNA. Int. J. Syst. Bacteriol. 41:240-246.

4. De Buyser, M.-L., A. Morvan, F. Grimont, and N. El Solh. 1989. Characterization of Staphylococcus species by ribosomal RNA gene restriction patterns. J. Gen. Microbiol. 135:989-999.

5. Farber, J. M., and J. I. Speirs. 1987. Potential use of continuous cell lines to distinguish between pathogenic and nonpathogenic Listeria spp. J. Clin. Microbiol. 25:1463-1466.

6. Feresu, S. B., and D. Jones. 1988. Taxonomic studies on Brochothrix, Erysipelothrix, Listeria, and atypical lactobacilli. J. Gen. Microbiol. 134:1165-1183.

7. Grimont, F., and P. A. D. Grimont. 1986. Ribosomal ribonucleic acid gene restriction patterns as potential taxonomic tools. Ann. 
Inst. Pasteur/Microbiol. (Paris) 137B:165-175.

8. Grimont, F., and P. A. D. Grimont. 1991. DNA fingerprinting, p 249-279. In E. Stakebrandt and M. Goodfellow (ed.), Nucleic acid techniques in bacterial systematics. John Wiley \& Sons Ltd., London.

9. Jacquet, C., S. Aubert, N. EI Sohl, and J. Rocourt. Use of rRNA gene restriction patterns for the identification of Listeria species. Syst. Appl. Microbiol., in press.

10. Lamont, R. J., D. T. Petrie, W. T. Melvin, and R. Postlethwaite. 1986. An investigation of the taxonomy of Listeria species by comparison of electrophoretic protein patterns, p. 45-49. In A. L. Courtieu, E. P. Espaze, and A. E. Reynaud (ed.), Listériose, Listeria, listeriosis. University of Nantes, Nantes, France.

11. Larsen, H. E., and H. P. R. Seeliger. 1966. A mannitol fermenting Listeria: Listeria grayi sp. n. In Proceedings of the Third International Symposium on Listeriosis, Bilthoven, The Netherlands.

12. Owen, R. J. 1989. Chromosomal DNA fingerprinting-a new method of species and strain identification applicable to microbial pathogens. J. Med. Microbiol. 30:89-99.

13. Rocourt, J., F. Grimont, P. A. D. Grimont, and H. P. R Seeliger. 1982. DNA relatedness among serovars of Listeria monocytogenes sensu lato. Curr. Microbiol. 7:383-388.

14. Rocourt, J., and H. P. R. Seeliger. 1985. Distribution des espèces du genre Listeria. Zentralbl. Bakteriol. Parasitenkd. Infektionskr. Hyg. Abt. 1 Orig. Reihe A 259:317-330.

15. Rocourt, J., U. Wehmeyer, P. Cossart, and E. Stackebrandt. 1987. Proposal to retain Listeria murrayi and Listeria grayi in the genus Listeria. Int. J. Syst. Bacteriol. 37:298-300.

16. Ruhland, G. J., and F. Fiedler. 1987. Occurrence and biochemistry of lipoteichoic acids in the genus Listeria. Syst. Appl. Microbiol. 9:40-46.

17. Seeliger, H. P. R., and K. Höhne. 1979. Serotyping of Listeria monocytogenes and related species, p. 33-48. In T. Bergan and
J. Norris (ed.), Methods in microbiology. Academic Press, New York.

18. Seeliger, H. P. R., and D. Jones. 1986. Genus Listeria Pirie 1940 p. 1235-1245. In P. H. A. Sneath, N. S. Mair, N. E. Sharpe, and J. G. Holt (ed.), Bergey's manual of systematic bacteriology, vol. 2. The Williams \& Wilkins Co., Baltimore.

19. Selander, R. K., D. A. Caugant, H. Ochman, J. M. Musser, M. N. Gilmour, and T. S. Whittam. 1986. Methods of multilocus enzyme electrophoresis for bacterial population genetics and systematics. Appl. Environ. Microbiol. 51:873-884.

20. Skerman, V. B. D., V. McGowan, and P. H. A. Sneath (ed.). 1980. Approved lists of bacterial names. Int. J. Syst. Bacteriol. 30:225-420.

21. Stuart, S. E., and H. J. Welshimer. 1973. Intrageneric relatedness of Listeria Pirie. Int. J. Syst. Bacteriol. 23:8-14.

22. Stuart, S. E., and H. J. Welshimer. 1974. Taxonomic reexamination of Listeria Pirie and tranfer of Listeria grayi and Listeria murrayi to a new genus, Murraya. Int. J. Syst. Bacteriol. 24:177-185.

23. Vazquez-Boland, J. A., L. Dominguez Rodriguez, J. F. Fernandez Garayzabal, J. L. Blanco Cancelo, E. Gomez-Lucia, V. Briones Dieste, and G. Suarez Fernandez. 1988. Serological studies on Listeria grayi and Listeria murrayi. J. Appl. Bacteriol. 64:371-378.

24. Wayne, L. G., D. J. Brenner, R. R. Colwell, P. A. D. Grimont, O. Kandler, M. I. Krichevsky, W. E. Moore, R. G. E. Murray, E. Stackebrandt, M. P. Starr, and H. G. Truper. 1987. Report of the Ad Hoc Committee on the Reconciliation of Approaches to Bacterial Systematics. Int. J. System. Bateriol. 37:463-464.

25. Welshimer, H. J., and A. L. Meredith. 1971. Listeria murrayi: a nitrate-reducing mannitol-fermenting Listeria. Int. J. Syst. Bacteriol. 21:3-7.

26. Wilkinson, B. J., and D. Jones. 1977. A numerical taxonomic survey of Listeria and related bacteria. J. Gen. Microbiol. 98:399-421. 